\title{
A vajdasági magyar ingázók nyelvi identitása és ideológiái
}

\author{
Linguistic identity and ideologies of Hungarian \\ commuters from Vojvodina
}

\author{
GÁBRITY ESZTER
}

KULCSSZAVAK: Vajdaság, ingázók, nyelvi identitás, ideológia

ABSZTRAKT: A tanulmány alapjául szolgáló kutatás célja a vajdasági magyar ingázók nyelvi identitásának és ideológiáinak behatóbb megismerése. A Szerbia és Magyarország között rendszeresen utazó, leginkább munkavállalási vagy tanulási célú ingázók a határ egyik és másik oldalán eltérő nyelvi közösségek, normák és elvárások hálójába kerülnek, melyhez sajátos módon próbálnak alkalmazkodni. A tanulmány arra keresi a választ, hogy vajon hogyan reagálnak a kutatás alanyai az eltérő nyelvi helyzetekre és azok kihívásaira, továbbá hogyan azonosulnak anyanyelvükkel (illetve annak mely változatával), végül pedig arra, hogy mindezeket a jelenségeket mely nyelvi ideológiák befolyásolják.

KEYWORDS: Hungarian commuters, Vojvodina, linguistic identity, language ideology

ABSTRACT: The present research focuses on the examination of Vojvodina Hungarian commuters' linguistic identity and ideology. The frequent travelers from Serbia to Hungary, who mostly commute between the two countries for labour and education purposes, face the necessity of interacting in differing linguistic communities defined by varying norms and expectations to which they need to adjust. The commuters whose mother tongue is the Contact Variety of Hungarian spoken in Vojvodina have to frequently, very often on a daily basis, communicate in Serbian and in the Standard Variety of Hungarian spoken in Hungary. As a consequence, they are continually required to define and redefine their linguistic identities. In this context the multilingual identity of the minority community exerts an identity-forming influence which provides the capability (for the members of the community) of easily crossing over between the communities of Serbs and Hungarians (in Hungary), but it also creates an "in-between" identity among the commuters. The language ideologies (beliefs, ideas) that dominate a speech community have a crucial impact on the speakers' linguistic identity and every-day language use, too. Ideologies related to languages, as well as their relationships, prestige and status, define and circumscribe the process of identification of the speakers with the various languages/language varieties they speak.

The study attempts to answer the question of how the research participants react to the various linguistic situations and their challenges, of how and to what extent they identify with their mother tongue (and with which dialect of it), and finally what language ideologies influence these linguistic phenomena.

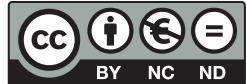




\section{Bevezetés}

Jelen tanulmány a Magyarország és Szerbia között ingázó vajdasági magyarok nyelvi identitásának és ideológiáinak kérdéskörével foglalkozik. A két-, illetve gyakran többnyelvű vajdasági magyar ingázók a határ egyik és másik oldalán más-más nyelvi környezettel, helyzettel szembesülnek; kettős kisebbségi helyzetben élnek. Egyrészt Szerbia hivatalos nyelve a szerb, ami a magyar nyelv használatának korlátozott lehetőségét eredményezi; a magyar nyelv gyakran a privát szférákba szorul vissza, míg a szerb nyelv a hivatalos szférákban és - vegyes családok, baráti társaságok esetén - a privát szférákban is dominál. Másrészt a Vajdaságban beszélt magyar nyelvváltozat több vonatkozásban is eltér a Magyarországon beszélt nyelvváltozattól. A vajdasági nyelvváltozat nyelvjárási, archaikusabb, továbbá szerb kontaktushatással tűzdelt jellege könnyen azonosíthatóvá teszi használóit, azaz a vajdasági magyarokat. A vajdasági magyar nyelvváltozat Magyarországon idegennek, furcsának vagy érdekesnek tűnhet, használói maguk is érezhetik levetkezendőnek vagy éppen megőrzendő, identitásukat kifejező értéknek.

A tanulmány kérdése az, hogy a két világ közötti ide-oda mozgás, az eltérő nyelvi helyzetek és az ezekből fakadó kihívások milyen hatással vannak a vajdasági magyar ingázók nyelvi identitására, s melyek azok a nyelvi ideológiák, amelyek az érintettek mindennapi nyelvhasználatát, illetve a nyelvről (nyelvekről) való gondolkodását befolyásolják. A tanulmány alapjául ingázókkal készített, félig strukturált mélyinterjúk szolgáltak. ${ }^{1} \mathrm{~A}$ kutatás során arra kerestem a választ, hogy vajdasági magyar ingázó interjúalanyaim miként használják a nyelvet identitásuk vagy éppen identitásaik kifejezésére, hogyan vélekednek a nyelv identitásformáló szerepéről, mennyire azonosulnak azokkal a nyelvekkel és nyelvváltozatokkal, amelyeket mindennapi szinten igen különböző közösségekben, környezetben használnak, s milyen attitüdökkel rendelkeznek ezekkel kapcsolatosan.

\section{Nyelvi identitás}

\section{Elméleti keretek}

A posztmodern kor embereiként nem egyetlen identitással, hanem identitásrepertoárral rendelkezünk (Barrett 1999). Az identitás nem stabil, statikus, egydimenziós jelenség, hanem sokdimenziós, többoldalú, dinamikus dolog, amely társadalmi konstrukcióként kontextushoz kötött, folytonosan képzett és újraképzett, tehát rekonstruálható, újradefiniálható és megváltoztatható (Kovács 2011; Omoniyi 2006; Thornborrow 1999). Antropológiai, szociológiai, szociál- 
pszichológiai és nyelvészeti kutatások szerint az identitás fluid, dinamikus és diszkurzív jelenség, mely adott kulturális és társadalmi közegben formálódik (Banquedano-López, Kattan 2007, 87.). Az identitás Tajfel $(1974,69$.$) szerint „az$ egyén adott társadalmi csoporthoz való tartozásának tudata, amely magába foglalja a csoporttagsággal járó, az adott csoport által képviselt értékrendszer és érzelmi jelenségek birtoklását is". Cameron (2001, 170.) hozzáteszi, hogy az egyén identitása sokrétű és sokszoros, helyzetektől, az adott társadalmi kontextus szereplőitől, elvárásaitól és gyakorlataitól függően folytonosan konstruálódik és újrakonstruálódik. Az egyén megalkotja és egyben elő is adja identitását, s ehhez verbális és nonverbális eszközök egyaránt rendelkezésére állnak (Banquedano-López, Kattan 2007). Az egyén önmaga pozitív identitásának kialakítására törekszik, s ha társadalmi, gazdasági, szociokulturális érdekei úgy kívánják, átalakítja identitását. Az identitás teremtése és újraalkotása során szükségszerűen kizáró és befogadó folyamatok zajlanak, hiszen önmagunkat másokhoz képest definiáljuk (Wodak 2012); a Gumperz nevéhez kötheto” „mi-ti” vagy „én-te” megkülönböztetés is rámutat arra, hogy önmagunk definiálása csak másokkal „szemben”, másokhoz képest valósulhat meg. A nyelvi identitás önmagunk - igen sokszor nem tudatos - megjelenítése a társadalmi világban nyelvek/nyelvváltozatok alkalmazásával. A nyelv olyan szemiotikai eszköz, amely alkalmas a társadalmi valóság és ezáltal az identitás közvetítésére (Bailey 2007, 341.), adott beszédhelyzetben nyelvhasználatunk révén identitásunkat is megjelenítjük mások számára. A nyelv túlmutat önmagán, a kommunikációs aktusok során nem csupán információközvetítés zajlik; a nyelv és nyelvhasználat lehetőséget ad arra, hogy különböző nyelvi eszközök révén megkülönböztessük magunkat azoktól, akiket másoknak tartunk (Niño-Murcia, Rothman 2008, 17.). A nyelvváltozatok teszik lehetővé, hogy önmagunk identitását a különböző társadalmi helyzetekben létrehozzuk, hogy jelezzük, kik vagyunk (vagy éppen kik nem vagyunk) (Tabouret-Keller 1998), azaz a nyelvi különbségek a társadalmi hovatartozást vagy a csoportba és közösségbe tartozást is jelzik (Cameron 1995, 15.; Joseph 2010). Az egyes kontextusokhoz társadalmi identitások és nyelvhasználati jegyek kapcsolódnak, ezért azok a nyelvek és nyelvváltozatok, amelyeket használunk, identitásunk építőköveivé válnak; nyelvhasználatunk elárulja, kik vagyunk (és kik nem vagyunk), milyen csoporttal azonosulunk, mely közösségbe tartozunk (Wodak 2012).

Kézenfekvő volna azt feltételeznünk, hogy a nyelvi változások és különbségek generálták (generálják) a csoportok és közösségek közötti eltéréseket, a kapcsolat iránya azonban fordított. Az egyes csoportok és közösségek a nyelvi eltérés eszközével juttatják egymás és saját maguk tudtára, hogy egymástól (valamilyen téren és valamilyen értelemben) eltérnek, elkülönülnek. A nyelvi különbözőségek teszik lehetővé a közösségek közötti határvonalak megvonását (Chambers 2003, 274.), a nyelvi különbözőségeket pedig azok a nyelvi normák és ideológiák tartják életben, amelyeket a közösségi gyakorlatok folytonosan létrehoznak és újratermelnek (Gal, Irvine 1995). Az adott közösségre vagy cso- 
portra jellemző nyelvi eszközök használata jelzéssel szolgál a beszélgetőpartner számára arról, hogy az egyén mely közösség tagjának vallja magát, s adott pillanatban és társadalmi helyzetben miként definiálja önmagát.

Többnyelvü közösségek esetében a rendelkezésre álló nyelvi repertoárok (és azok nyelvi változatai) összetettebb nyelvi viszonyrendszert alkotnak, amelyben az egyén öndefiniálási folyamatait jelentős mértékben befolyásolja az egyes nyelvek hatalmi státusza és viszonya. Az e közösségekben jelen levő nyelvek - attól függően, hogy a társadalmi, gazdasági, politikai viszonyok miként alakulnak az egyes nyelveket beszélő csoportok között - hierarchikus viszonyokba rendeződnek. Az esetek jellemző többségében a többségi nemzet nyelve domináns helyzetbe kerül a kisebbségi nyelv(ek)hez képest, nemcsak a beszélők abszolút és relatív többségéből eredően, hanem abból fakadóan is, hogy a nyelvhez társított gyakorlatok közvetlenül kapcsolódnak hatalmi, döntési helyzetekhez, sokkal gyakoribbak és tágabbak a többségi nyelv nyelvhasználati színterei. Továbbá a kisebbségi nyelvvel (nyelvekkel) szemben a többségi nyelv használata legitim. Ily módon közvetlenül, gyakran észrevétlenül válik a domináns nemzet nyelve a siker, a hatalom és az érvényesülés eszközévé és egyben jelképévé mind a többségi, mind a kisebbségi csoportok szemében. Amennyiben a kisebbségi csoporthoz tartozók nem beszélik a többségi nemzet nyelvét, komoly hátrányokkal és korlátokkal szembesülnek, s ez társadalmi, gazdasági sikertelenséget, kudarcot eredményez. Ebben a hatalmi rendszerben az a körülmény, hogy kisebbségi csoportokhoz tartozók mely nyelvvel azonosulnak, értékes információt szolgáltat arról, hogy asszimilációjuk vagy integrációjuk a többségi nemzetbe milyen mértékủ és milyen minőségü. Értelmezésem szerint az asszimiláció a kisebbségben lévők társadalmi többségbe való beolvadását jelenti, ezzel szemben az integráció során a beilleszkedés nem jár a kisebbségi identitás elvesztésével.

\section{Többnyelvü identitás}

Az általunk megkérdezett interjúalanyok többnyelvünek vallják magukat, a többnyelvüség identitásuk részét képezi; úgy gondolják, hogy egyedivé teszi és megkülönbözteti őket mind a szerbiai, mind a magyarországi közösségtől, hiszen egyik közösségre sem jellemző a szomszédos (nem világ)nyelvek ismerete és mindennapi használata. E kontextusban a kisebbségi közösség többnyelvűségének identitásformáló ereje van, amely egyfajta átjárhatóságot biztosít a két közösség, azaz a magyarországi magyar és a szerbiai szerb közösség között, de egyben egy „köztes” identitást is létrehoz. A szerb-magyar kétnyelvűség a vajdasági magyar nyelvi identitás szerves része. Valamennyi interjúalanyunk arról számolt be, hogy több mint egy nyelvet ismer, többségük három nyelv ismeretével büszkélkedik. Magyar anyanyelvükön kívül a szerb és valamely világnyelv (leggyakrabban angol, német, orosz) ismerete, használata jellemzi őket. A többnyelvűséget értéknek tekintik, amely előnyökkel kecsegtet, a munkaerőpiacon, 
és a társadalmi, közösségi életben egyaránt. Úgy is fogalmazhatunk, hogy a többnyelvűség hasznosítható tőkét jelent mind a vajdasági, mind a magyarországi környezetben.

Árpád és Ernő a többnyelvűség gazdasági hasznáról beszélnek, hiszen számukra előnyt jelent a munkaszerzésben, valamint sikeresebb munkavégzést tesz lehetővé az, hogy a magyar és szerb mellett egy világnyelv is birtokukban van. „Hát elönyöm az származott abból, hogy két nyelvet tudok, mert hogyha munkát kerestem, akkor természetesen ugyanúgy a fönökkel is szerbül is el tudtam beszélgetni, hogyha szerb fönököm volt, vagy ha magyar fönököm volt, akkor természetesen magyarul. Úgyhogy mindenképpen elönyöm volt ebból." (Árpád, 24 éves, jelenleg munkanélküli, ingázó)

„Az, hogy több nyelven tudok kommunikálni, megértetni magam, az számos helyen kamatoztatta már magát. Ugye többek között az is, hogy könnyen feltaláltam magam külföldön, tudtam tanulni, munkát végezni, illetve jelenleg is a munkám során napi rendszerességgel kell, hogy beszélgessek németországi kollégákkal, és velük németül, illetve angolul tudok kommunikálni. Tehát megkönnyiti a munkavégzésemet is, és segit abban, hogy föltaláljam magam külföldön." (Ernő, 26 éves, programtervező matematikus egy multinacionális cégnél, ingázó)

Attila szerint mások nyelvének ismerete nagyobb lehetőséget nyújt az emberi kapcsolatok és barátságok elmélyítésére:

„A többnyelvüség pont a barátság miatt fontos, tehát angolul lehet kommunikálni bárkivel, barátságokat viszont elsősorban úgy lehet kötni, ha tudjuk a másiknak a nyelvét, vagy ha ö tudja a miénket, tehát az mindig, tehát az mindig közelibb... Mindig azon keresztül lehet barátságokat kötni. Tehát tanulni kell idegen nyelveket, nem megelégedni csak a saját anyanyelvünkkel." (Attila, 49 éves, történész egy szerbiai múzeumban, ingázó)

Judit ugyanakkor többnyelvüségének egy másik oldalát mutatja be. Magyarországi munkahelyén a szerb amolyan titkos nyelvként szolgál. A vajdasági magyar kollégákkal szerbül beszélve egyrészt kivonhatják magukat a többiek ellenőrzése alól, másrészt ezzel mind kollégáik felé, mind önmaguk számára kifejezhetik összetartozásukat, közös hátterüket, identitásukat.

„A szerb nyelvet, azt most Magyarországon nem kell olyan nagyon [használni], akkor beszélünk szerbül, ha nem akarjuk, hogy az erdélyiek vagy a magyarok megértsék, egymás között mi vajdaságiak, de nincsen rá szükség, mert a gyárban nem dolgozhat olyan ember, aki nem tud magyarul." (Judit, 52 éves, gyári munkás egy autóalkatrészeket előállító külföldi cégnél, ingázó)

\section{Vajdasági magyar identitás: mi és ôk}

A vajdasági (és más Kárpát-medencei magyar) közösség kisebbségi helyzete többek között azt jelenti, hogy a magyar anyanyelvü közösség egy másik ország ré- 
szévé vált és eltávolodott a központi magyarországi nyelvterülettől. Abból fakadóan, hogy a kisebbségi magyar közösségek nem csupán földrajzi, de társadalmi értelemben is a magyar nyelvközösség peremére kerültek, továbbra is fennmaradtak az archaikusabb, nyelvjárási jellegű nyelvi formák, és a nyelvi konzervativizmus is erősebb hatással van a nyelvre és a nyelvről való gondolkodásra (Csernicskó, Szabómihály 2010). A Vajdaságban használt nyelvváltozat jellemzően a fonéma, morféma, lexéma szintjén is eltér a többi magyar nyelvváltozattól, és a nyelvhasználatot a kétnyelvű egyénekre és közösségre egyaránt jellemző kódváltások és kódkeverések jellemzik (Kontra 2006). A vajdasági magyar nyelvváltozat(ok)ra legjellemzőbb a szókincsben megfigyelhető eltérés, amely a szerb nyelvvel való kontaktus hatása. A vajdasági magyarok magyar nyelvü beszélgetéseik során is gyakran használnak közbeékelt szerb szavakat és szófordulatokat. Emellett egyes hangokat is másképp formálnak, mint a magyarországiak. A szerb nyelv kisebb hatással volt/van a Vajdaságban beszélt magyar nyelv grammatikájára. A többségi nyelv hatásaként bizonyos nyelvtani szerkezeteket a vajdasági magyarok gyakrabban használnak, mint a magyarországiak (pl. feminizálás, azaz a tanárnő, igazgatónő, doktornő gyakoribb használata olyan esetekben is, amikor a megjelölés nem szükséges; redundáns névmások használata, mint például az alábbi esetben: „Tegnap láttalak téged a tévében.”).

A Vajdaság területén beszélt nyelvváltozat tehát - amelyre az interjúalanyok anyanyelvként tekintenek, amellyel azonosulnak - eltér a Magyarország területén használt nyelvváltozattól (mind a standard, mind pedig a tájnyelvi változatoktól). Az adatközlők számos alkalommal számoltak be arról, hogy maguk és a magyarországi közösség tagjai is észrevették, illetve megjegyezték, hogy másképpen beszélik a közös magyar nyelvet. A beszámolók szerint a magyarországiak különböző módon reagálnak a nyelvi eltérésekre: vannak, akik szóvá teszik, mások nem jelzik, hogy esetlegesen nem értik a vajdasági beszélőt.

„Volt, hogy többször meg... többször volt, hogy megjegyezték ezt, igazából nem rosszindulattal, valaki tetszését nyilvánitotta ki, de olyan még nem volt, hogy valaki rossz szót mondott volna azért vagy rossz véleményt mondott volna rólam azért, mert más akcentussal beszélek." (Ernő, 26 éves, programtervező matematikus egy multinacionális cégnél, ingázó)

„....használok olyan szavakat, amik, amik csak Vajdaságra jellemzők. Ekkor általában bambán néznek, nem nagyon szoktak visszakérdezni, hogy mire gondoltam, mit jelent..." (Endre, 28 éves, villamosmérnök egy nemzetközi cégnél, ingázó)

A vajdasági ingázók egyetértenek abban, hogy közösségük meglehetősen sok szót, kifejezést kölcsönzött a többségi (szerb) nemzettől. Annak ellenére, hogy a nyelvek keveredését a közösség tagjai gyakran negatívan ítélik meg, az mégis hozzájárul a vajdasági magyar kétnyelvű közösség nyelvi identitásának formálódásához. A két nyelv bizonyos szintủ keverése, összemosódása egyedivé teszi a közösség tagjait, és két irányban is hozzájárul a „mi-ti” elkülönítéséhez, vagyis a magyarországi magyaroktól és a szerbektől való különbözőség kifejezéséhez. 
„...azt mondom, hogy különbözött, mert a vajdaságiak különböző szerb szavakat átvettek, magyarositottak úgymond, és azt ők beépitették a saját szótárjukba, amit a magyarországi magyarok nem ismernek. Tehát valamilyen szinten eltér a két nyelv idézőjelben egymástól." (Árpád, 24 éves, munkanélküli, ingázó)

„Az, ami jellemző a vajdasági magyar nyelvre, hogy elég sok szót átveszünk a szerbból, remélem ez a tendencia nem fog folytatódni, és remélem, hogy nem felejtünk el magyarul." (Ernő, 26 éves, programtervező matematikus, ingázó) „Nekem abban különbözött, hogy miránk is ránkragadnak a szerbektöl különbözö kifejezések, amiket egyszerübb itten használnunk magunk között, mint hogy a magyar kifejezést keressük rá. Például a ragasztószalagot szelotépnek hívjuk, vagy hogyha tömeg volt valahol a buszban vagy valahol, akkor azt mondjuk, hogy gúzsva." (Judit, 52 éves, gyári munkás, ingázó)

\section{A transznacionális gondolkodás csírái}

Az egymást kizáró vagy egymással ellentétes identitások is gyakran megférnek egymás mellett. Mivel az egyén alapvetően pozitív azonosulásokra törekszik (Hamers, Blanc 2000), ezért az egymással ellentétben álló vagy összeférhetetlen identitásokat igyekszünk valamilyen módon összeegyeztethetővé tenni. A vajdasági magyar ingázók, ha különböző módon és intenzitással is, de gazdasági, társadalmi, történelmi vonatkozásban, családi és érzelmi szinten két országhoz kötődnek, ami kettős identitást vagy éppen az identitás meghatározásának nehézségét idézheti elő. Az állapot feloldása érdekében az adatközlők a transznacionális életmódra és gondolkodásra jellemző, kétlaki életvitelt folytatnak.

„Itt most már nem annyira országhoz kötődik a viselkedési forma, hanem inkább egyfajta kultúrtérséghez, és... és itt a határok kezdenek elmosódni." (Attila, 49 éves, történész, ingázó)

A transznacionális életmóddal járó, a közösségek, világok közötti gyakori mobilitás eredményeképpen a vajdasági magyar ingázók gyakran számolnak be arról, hogy gyorsan és tudatosan váltanak a vajdasági nyelvváltozatról a magyarországi standard nyelvváltozatra, amint a határt átlépve Magyarországra érnek.

„Tehát pont ezért, ezek a szavak elkerülése végett, hogy megértsük egymást, akkor természetesen azokat a pár szókülönbségeket akkor változtatom meg, meg szoktam változtatni. Tehát inkább úgy mondanám, hogy a szülőhazámban úgy beszélek, mint ahogyan szoktam, csak itt az olyan emberekkel, akik magyarországiak, akkor szoktam úgymond idézőjelben más nyelven beszélni, más szavakkal” (Árpád, 24 éves, munkanélküli, ingázó)

„De én nagyon gyorsan tudok alkalmazkodni, rögtön átváltok, hogyha már látom, kimondtam valamit, hogy például mi azt mondjuk örökíró, ők azt mondják toll..." (Judit, 52 éves, gyári munkás, ingázó)

„...átléptem a határon, akkor másképp beszélek. Akár az egyik vagy a másik 
oldalra, mivelhogy most Magyarországon dolgozom, ottan rám ragadtak ezek a kifejezések, tehát lényegében magyarabbak, mint amiket mink használunk, akkor itt is úgy beszélek. Hogy ha tovább itthon vagyok, akkor visszaragadnak rám a megszokott szavak." (Judit, 52 éves, gyári munkás, ingázó)

\section{Nyelvi ideológiák}

\section{Elméleti keretek}

Az ideológia olyan vélemény- és nézetrendszer, amely széles körü konszenzuson alapul, amelyet rendszerint megkérdőjelezhetetlen igazságnak tekintünk, nem vonunk kétségbe, s amelyet magunk is napról napra újratermelünk. A nyelvi ideológiák korántsem csak a nyelvről szólnak, tükröződnek bennük az adott társadalmat, közösséget jellemző viszony- és hatalmi rendszerek is. A nyelvi ideológiák a nyelvhasználatban kerülnek felszínre: abban, ahogyan az emberek a nyelvet használják (illetve nem használják); abban, hogy mit tartanak nyelvileg helyesnek; abban, hogy mely nyelvváltozatot hol, mikor és kivel beszélik (Lanza 2007); hogy miként gondolkodnak a beszélők a nyelvekről/nyelvváltozatokról; hogy milyen rejtett, kétségbevonhatatlannak tűnő elvek irányítják a nyelvhasználatot; végül hogy mely nyelveket és nyelvváltozatokat övezik pozitív és negatív vélemények (Lanstyák 2009). Az egyes nyelvi ideológiák kialakulása (vagy kialakítása) és fenntartása, a nyelvek/nyelvváltozatok között megteremtett viszonyrendszer rámutat a nyelvek beszélőinek hatalmi viszonyrendszerére. A nyelvi ideológiák valamely csoport (vagy csoportok) szinte észrevétlen gazdasági, hatalmi előnyének képviseletére jönnek létre egy adott társadalmi és kulturális viszonyrendszerben (Kroskrity 2004). Az, hogy mely csoportok nyelve/nyelvváltozata élvez magas presztízst és elismerést, rámutat arra is, hogy mely csoportok birtokolják a hatalmat, illetve befolyásolják a döntéseket (Irvine, Gal 2000; Lanstyák 2009; Woolard, Schieffelin 1994).

A nyelvi ideológia fogalmát Gal (2002, 197.; Laihonen 2011, 20. fordítása) az alábbi módon határozza meg: „A nyelvideológiák kultúrafüggő fogalmak, amelyeket a résztvevők és megfigyelők visznek bele a nyelvbe, gondolatok arról, mire jó a nyelv, mit jeleznek az egyes nyelvi formák azokról az emberekről, akik ezeket használják, illetve egyáltalában miért vannak nyelvi különbségek." A nyelvi ideológiák kialakulása és újratermelése kulturális, társadalmi, gazdasági és politikai intézményrendszereken keresztül zajlik, mögöttük gazdasági, politikai, társadalmi és hatalmi érdekek bújnak meg, s a nyelvi ideológiák egyes csoportok érdekeinek megfelelő módon fejtik ki hatásukat a közösség egyes tagjaira (Irvine, Gal 2000; Lanstyák 2009; Silverstein 1979).

A nyelvi ideológiák egyik legfontosabb funkciója a nyelvi alapú azonosítás (beazonosítás) és megkülönböztetés. Az egyes beszélőközösségek tagjai hajla- 
mosak úgy tekinteni a nyelvi különbségekre, mint ha azok tulajdonképpen az egyes közösségek különbözőségét jelölnék. E kapcsolat valójában fordított irányú: az egyes közösségek nyelvi különbségei és különbözőségei abból a célból születnek, hogy általuk elhatárolhassák, elkülöníthessék magukat más közösségektől. A nyelvi ideológiák a különbségek racionalizálásában és a hierarchiarendszer indoklásában segítenek (Irvine, Gal 2000). Bármilyen nyelvi elem, bármely nyelvi szinten (fonológia, morfológia, szintaxis, lexika, pragmatika) alkalmas egy csoport másoktól való elkülönítésére. Először egy nyelvi elem (nyelv, dialektus, nyelvváltozat vagy egy nyelvi változó) indexikussá válik egy társadalmi csoport nyelvhasználatában, vagyis alkalmas lesz arra, hogy közvetlen kapcsolatot fedezhessünk fel a nyelvi változó és a csoport között. Tehát ha valaki egy bizonyos nyelvet/dialektust/nyelvváltozatot vagy egy nyelvi változó adott nyelvi változatát használja, a hallgatóság azzal a csoporttal hozza kapcsolatba és azonosítja, amelyben az adott nyelv/dialektus stb. használatos. A nyelvi ideológiák révén az egyes nyelvi különbségek társadalmi értelmezést, ezáltal „értéket” kapnak, azaz egyes nyelvi elemek megítélése pozitív, másoké viszont negatív lesz. Az ideológiák teszik lehetővé azt, hogy ne a közösséget értékeljük, hanem annak nyelvhasználatáról ítélkezzünk pozitívan vagy negatívan, ami természetesen a közösségre is rávetül (Irvine, Gal 2000; Woolard, Schieffelin 1994).

Többnyelvü közösségekben a beszélőközösség nyelvi repertoárja bővebb, a közösség nyelvi mintázata is összetettebb; a mindennapi interakciókban több nyelv és annak nyelvváltozatai, dialektusai jelennek meg. Korábbi ismereteink szerint a domináns közösség nyelve élvez legmagasabb elismerést és presztízst, amely egyben a döntéskozó, hatalmi helyzetben levő intézmények nyelve/nyelvváltozata. A közösségben használt egyes nyelvek hierarchikus viszonyba rendeződnek. Leggyakrabban az ország hivatalos nyelve (és annak is standard változata) válik a hegemón intézmények nyelvévé, melynek fennmaradását és meglétét (továbbá újratermelését) a nyelvi ideológiák teszik lehetővé. Az egyik nyelv magasabb presztízse a másikhoz képest a nyelvek beszélőinek észlelt hatalmi egyenlőtlenségéből ered (Romaine 2004). A többségi nyelv - annak eredményeképpen, hogy a domináns nemzet vagy nemzeti elit használja és beszéli - hegemón helyzetbe kerül a többi nyelvvel (vagy nyelvváltozattal) szemben. A domináns nyelvi ideológia nemcsak a többség, de a kisebbségek ideológiájává is válik, hiszen azt a benyomást kelti, hogy azok vannak döntéshozó, hatalmi pozícióban, akik az adott nyelvet/nyelvváltozatot beszélik; vagyis adott nyelvnek magasabb az értéke, megbecsülése az élet bármely területén (politika, munkapiac, kultúra, média, oktatás stb.), mint más, egyéb nyelveknek (Blackledge 2000). A befolyással és hatalommal rendelkező intézmények és intézményrendszerek nyelvi gyakorlataik révén legitimálják azokat a nyelveket (leginkább a többség nyelvét) és nyelvváltozatokat (a standard nyelvváltozatot), amelyeket tulajdonképpen az elitnemzet vagy elitcsoport beszél, így biztosítva nemcsak gazdasági, hatalmi, de nyelvi fölényt és előnyt is. A hatalmi kiváltságok megőrzésének egyik láthatatlan eszköze a nyelv/nyelvváltozat felügyelete (McLaren 1999). A nyelvi ideológiák 
fenntartják és újratermelik a társadalmi különbségeket az eltérő nyelvek (és nyelvváltozatok) beszélői között, ugyanis a kétnyelvű egyén könnyen azonosíthatóvá válik a többnyelvűekre jellemző, nyelvi kontaktusokkal tűzdelt nyelvhasználat révén, ami az alsóbbrendűség érzetének kialakulásához vezethet (Tabouret-Keller 1998).

\section{A vajdasági kontaktusváltozattal és a magyarországi standard nyelvváltozattal kapcsolatos nyelvi ideológiák}

A legelterjedtebb nyelvi ideológiák egyike az úgynevezett nyelvi standardizmus. Lényege, hogy a beszélők egy adott nyelvváltozatot nyelvi szempontból magasabb rendűnek, jobbnak, szebbnek, tökéletesebbnek, kifejezőbbnek vélnek, és erre a változatra tekintenek normaként. Az ideológia azt sugallja, hogy az adott nyelvváltozat felsőbbrendü a többi nyelvváltozathoz (általában nyelvjáráshoz) képest, amelyek tökéletlenek, kevésbé szépek, sok esetben pedig egyenesen helytelenek. Nem meglepo", hogy az a nyelvváltozat, melyre standardként tekintenek, minden esetben ahhoz a csoporthoz köthetö, amely a hatalmi rendszer legfelső fokán foglal helyet (Lanstyák 2009; Milroy 2001). A kutatás kontextusában a Magyarországon használt standard magyar nyelvváltozat képezi a nyelvhasználat modelljét, a közösség azt tekinti követendő mintának, így a vajdasági magyarok a magyarországi standardhoz viszonyítják nyelvhasználatukat.

A vajdasági magyar ingázók körében jellemzo, hogy saját vajdasági nyelvváltozatukat - annak ellenére, hogy szebbnek találják a magyarországinál - nem tartják helyesnek, eléggé „magyarnak”, hanem idegen (szerb) szavakkal tüzdelt, nem tiszta, kevésbé kifinomult és kifejező nyelvváltozatnak tekintik. A szerb és a magyar nyelv nyelvhasználatukban megjelenő kontaktushatásait nem a kétnyelvüség természetes velejárójaként tartják számon, hanem negatívumként, hibaként, amelyet meg kell szüntetni, ki kell irtani. Az interjúalanyok többször beszéltek azon törekvésükről, hogy „helyesen, választékosan” beszéljenek, vagyis a magyarországi magyar nyelvváltozatot használják, annak ellenére, hogy nagyobb mértékben azonosulnak a vajdasági (anyanyelvi) nyelvváltozattal.

,....mert vannak biztosan olyanok is, akik, hogy mondjam, ha meghallják, hogy az ember mondjuk szerbül beszél, akkor hát rájönnek tulajdonképpen, hogy nem igazi magyar úgymond, hanem inkább tehát hát Vajdaságból jött magyar, és akkor hát lehet, hogy ilyen szempontból eleshetnek valamilyen elónyöktól vagy munkától" (...) Igyekszek helyesen beszélni, azt a részét, amit úgy látom, hogy a vajdaságiakban helytelen, azokat nem folytatom... az igazság, hogy a magyarországi nyelvhasználatban egyes dolgokat, hogy mondjam, árnyékoltabban is kifejeznek, míg itten, hogy mondjam, egyszerübben..." (Róbert, 59 éves, villamosmérnök, ingázó)

„De amióta itt vagyok, úgymond átvettem az itteni helyes szavakat, amit kell használni az adott dolgokra, úgyhogy ebböl nincs probléma" (Árpád, 24 éves, munkanélküli, ingázó) 
„Bár én igyekszem, hogy tisztán beszéljek magyarul itten Szerbia területén is, de hát ez észrevétlenül is ránk ragad" (...) mégiscsak vigyázni kell, hogy ne túl sok idegen kifejezést keverjünk bele. Figyelni kell rá, mert észrevétlenül is beleszivárog a beszédünkbe a szerb vagy az idegen kifejezés, de ezt nem volna szabad megengedni szerintem." (Judit, 52 éves, gyári munkás, ingázó)

\section{Az államnyelvvel kapcsolatos nyelvi ideológiák}

A domináns nemzet nyelvi ideológiái erős hatással vannak a kisebbségek nyelvi ideológiáira is, ami leginkább a többségi nemzetnek kedvező nyelvi ideológiákban nyilvánul meg. A talán legelterjedtebb ideológia szerint a kisebbségben élő közösség magától értetődő kötelessége és felelőssége az államnyelv elsajátítása és számos színtéren való elvárt (kötelező) használata. Az ideológia hatékony múködését jelzi, hogy sem a többségi, sem a kisebbségi nemzet nem vonja kétségbe jogosságát, senkiben sem merül fel (legalábbis nyilvánosan), miért nem kétoldalú a kétnyelvűség, azaz a többségi nemzet miért nem beszéli/tanulja meg a kisebbség nyelvét, miért kizárólag a kisebbség kötelessége, hogy beszélje/tanulja a többségi nemzet nyelvét. Az ideológia beágyazottságának sikerességét bizonyítják a következő interjúrészletek, melyekben burkolt, rejtett módon megfigyelhetőek az államnyelvvel szembeni nyelvi ideológiák.

Kérdés: "És milyen gyakran és kivel szoktad használni az idegen nyelveket?" Attila: „Hát a szerb az ugye egyértelmü, azt... azt nem is... tehát azt tényleg nem tekintem idegen nyelvnek" (Attila, 49 éves, történész, ingázó)

„Hát itthon, amikor hazajövök, természetesen, hogy piacon, boltban, hivatalos helyeken, bankban, rendörségen, ahol nem tudnak magyarul, ott én önként átváltok szerbre, mivelhogy én könnyen beszélem... Sokan tudnak a hivatalos helyeken is magyarul szerb ajkúak is, de én akkor szívesen beszélek szerbül, mert én, ha én jobban tudok beszélni mint ő, akkor inkább szerbül beszélünk.” (Judit, 52 éves, gyári munkás, ingázó)

\section{Összegzés}

Tanulmányom rámutatott arra, hogy a vajdasági magyar ingázók erősen ragaszkodnak regionális (vajdasági) identitásukhoz, ami nyelvi önazonosságukban is jelentkezik. Transznacionális - két országhoz, két világhoz kötődő - életmódjukból adódóan megjelenik a nyelvek és nyelvváltozatok közötti váltás jelensége is, amely biztosítani képes a különböző (vajdasági, magyarországi magyar és szerb) nyelvi közösségekhez való alkalmazkodást, emellett egyensúlyban tartja az egyes identitásokat. A kutatás keretében megkérdezett ingázók - függetlenül attól, hogy Magyarországon vagy Szerbiában élnek - rendkívül hasonló ideológi- 
ákkal rendelkeznek, amelyek egybeesnek a többségi nemzet(ek) által közvetített nyelvi ideológiákkal. A domináns nyelvi ideológiák sikeresen beépülnek a kisebbségi közösség tagjainak tudatába is, s ez észrevétlenül fejti ki hatását a közösség nyelvről való vélekedéseire, a nyelvek hasznosságának megítélésére.

\section{Jegyzet}

1 A szabadkai kutatócsoport összesen 34 migránssal (18 férfi, 16 nő) és 13 ingázóval (10 férfi, 3 nő) készített interjúkat 2011 folyamán, különböző vajdasági és magyarországi településeken (Szabadka, Zenta, Budapest, Szeged, Kanizsa, Ada stb.). Interjúalanyaink korukat, iskolai végzettségüket, foglalkozásukat, valamint a migrációt/ingázást kiváltó okokat illetően is különböznek egymástól. A tanulmányban az ingázókkal készített interjúkra támaszkodom.

\section{Irodalom}

Bailey, B. (2007): Multilingual forms of talk and identity work. In: Auer, P., Wei, L. (eds.): Handbook of multilingualism and multilingual communication. Mouton de Gruyter, Berlin, 341-370.

Banquedano-López, P., Kattan, S. (2007): Growing up in a multilingual community: insights from language socialization. In: Auer, P., Wei, L. (eds.): Handbook of multilingualism and multilingual communication. Mouton de Gruyter, Berlin, 69-99.

Barrett, R. (1999): Indexing polyphonous identity in the speech of African American drag queens. In: Bucholtz, M., Liang, A. C., Sutton, L. A. (eds.): Reinventing identities: the gendered self in discourse. Oxford University Press, New York, 313-331.

Blackledge, A. (2000): Monolingual ideologies in multilingual states: Language, hegemony and social justice in Western liberal democracies. Estudios de Sociolingüística, 2., 24-45.

Cameron, D. (1995): Verbal hygiene. The politics of language. Routledge, London

Cameron, D. (2001): Working with spoken discourse. Sage, London

Chambers, J. K. (2003): Sociolinguistic theory: linguistic variation and its social significance. Blackwell, Oxford

Csernicskó I., Szabómihály G. (2010): Hátrányból előnyt: a magyar nyelvpolitika és nyelvtervezés kihívásairól. In: Bitskey B. (szerk.) Határon túli magyarság a 21. században. KEH, Budapest, 167-198.

Gal, S. (2002): Language ideologies and linguistic diversity: where culture meets power. In: Keresztes I., Maticsák S. (szerk.): A magyar nyelv idegenben. Debreceni Egyetem, Debrecen, 197-204.

Gal, S., Irvine, J. (1995): The boundaries of languages and disciplines: how ideologies construct difference. Social Research, 4., 967-1001.

Hamers, J. F., Blanc, M. H. A. (2000): Social psychological aspects of bilinguality: culture and identity. In: Hamers, J. F., Blanc, M. H. A. (eds.) Bilinguality and bilingualism. Cambridge University Press, Cambridge, 198-240.

Irvine, J., Gal, S. (2000): Language ideology and linguistic differentiation. In: Kroskrity, P. V. (ed.): Regimes of language: ideologies, polities, and identities. School of American Research Press, Santa $\mathrm{Fe}, 35-84$.

Joseph, J. E. (2010): Identity. In: Llamas, C., Watt, D. (eds.): Language and identities. Edinburgh University Press, Edinburgh, 9-17. 
Kontra M. (2006). A határon túli magyar nyelvváltozatok. In: Kiefer, F. (szerk.): Magyar nyelv. Akadémiai Kiadó, Budapest, 549-576. (Akadémiai Kézikönyvek)

Kovács, M. (2011). Ethnic and linguistic identities of Hungarians and their descendants in Finland. In: Grünthal, R., Kovács, M. (eds.): Ethnic and linguistic context of identity: Finno-Ugric minorities. 121-159. (Uralica Helsingiensia; 5.)

Kroskrity, P. (2004). Language ideologies. In: Duranti, A. (ed.): A companion to linguistic anthropology. Blackwell, Oxford, 496-517.

Laihonen, P. (2011): A nyelvideológiák elmélete és használhatósága a magyar nyelvvel kapcsolatos kutatásokban. In: Hires-László K., Karmacsi Z., Márku A. (szerk.): Nyelvi mítoszok, ideológiák, nyelvpolitika és nyelvi emberi jogok Közép-Európában elméletben és gyakorlatban. Tinta Könyvkiadó, II. Rákóczi Ferenc Kárpátaljai Magyar Főiskola Hodinka Antal Intézete, Budapest, Beregszász, 20-27.

Lanstyák, I. (2009). Nyelvi ideológiák és filozófiák. Fórum Társadalomtudományi Szemle, 1., 27-44.

Lanza, E. (2007). Multilingualism and the family. In: Auer, P., Wei, L. (eds.): Handbook of multilingualism and multilingual communication. Mouton de Gruyter, Berlin, 45-67.

McLaren, P. (1999). Life in schools: an introduction to critical pedagogy in the foundations of education. Longman, New York

Milroy, J. (2001): Language ideologies and the consequences of standardization. Journal of Sociolinguistics, 4., 530-555.

Niño-Murcia, M., Rothman, J. (2008): Spanish-contact bilingualism and identity. In: Niño-Murcia, M., Rothman, J. (eds.): Bilingualism and identity: Spanish at the crossroads with other languages. John Benjamins Publishing Company, Amsterdam, Philadelphia, 11-32.

Omoniyi, T. (2006): Hierarchy of identities. In: Omoniyi, T., White, G. (eds.): The sociolinguistics of identity. Continuum, New York, 11-33.

Romaine, S. (2004): The bilingual and multilingual community. In: Bhatia, T. K., Ritchie, W. C. (eds.): The handbook of bilingualism. Blackwell, Oxford, 385-405.

Silverstein, M. (1979): Language structure and linguistic ideology. In: Clyne, P. R., Hanks, W. F., Hofbauer, C. J. (eds.): The elements: a parasession on linguistic units and levels. Chicago Linguistic Society, Chicago, 193-247.

Tabouret-Keller A. (1998): Language and identity. In: Coulmas F. (ed.): The handbook of sociolinguistics. Blackwell, Oxford, 315-326.

Tajfel, H. (1974): Intergroup behavior, social comparison and social change, Katz-Newcomb Lectures. University of Michigan, Ann Arbor

Thornborrow, J. (1999): Language and identity. In: Thomas, L., Wareing, S., Singh, I., Stilwell Peccei, J., Thornborrow, J., Jones, J. (eds.): Language, society and power. Routledge, London, 157-172.

Wodak R. (2012): Language, power and identity. Language Teaching: Surveys and Studies, 2., 215-233.

Woolard, K. A., Schieffelin, B. B. (1994): Language ideology. Annual Reviews in Anthropology, 23., 55-82. 